\title{
Short Communication: Analysis of weed vegetation in immature and mature oil palm plantations
}

\author{
HALUS SATRIAWAN", ZAHRUL FUADY \\ Program of Agrotechnology, Faculty of Agriculture, Universitas Almuslim. Jl. Almuslim No. 1, Matang Glumpang Dua, Peusangan, Bireuen 24261, \\ Aceh, Indonesia. Tel.: +62-644-442166, •email: satriawan_80@yahoo.co.id
}

Manuscript received: 18 July 2019. Revision accepted: 24 October 2019.

\begin{abstract}
Satriawan H, Fuady Z. 2019. Analysis of weed vegetation in immature and mature oil palm plantations. Biodiversitas 20: 3292-3298. The species of weeds which grow and dominate in palm oil areas depend on location, local climate, and the light received. This research aimed to determine the diversity of weeds in the planting of palm oil with a different age grown in 2012, 2013, 2014 and 2016. The sample slots measured uniformly at $1 \mathrm{~m} \mathrm{x} 1 \mathrm{~m}$ totaling 25 plots. Vegetation analysis was conducted to the density (D), relative density (RD), frequency (F), relative frequency (RF), important value index (IVI), Summed Dominance Ratio (SDR), and Species Diversity Index $\left(\mathrm{H}^{\prime}\right)$. Weed composition includes 21 families with 36 species, with the total number of each individual during the year of palm oil planting was 3540,3148,3731, and 2910. The relative density value of the highest weeds in the planting year group in 2012 and 2013 were Asystasia intrusa (20.22\% and 21.05\%), in 2014 were Eleusine indica (23.93\%) and 2016 were Cynodon dactylon with $24.49 \%$. The importance value of weeds in four groups in planting year of oil palm was also in line with the relative density value. These were A. intrusa in 2012 and 2013, amounting to 27.41 and 27.95 and in 2014 and 2016, totaling to 23.72 and 37.64 was E. indica and C. dactylon. The value of the highest species diversity of 6.85 was found in the year 2014 , followed by 2012 with 5.88.
\end{abstract}

Keywords: Asystasia intrusa Cynodon dactylon, diversity, Eleusine indica, oil palm, weeds

\section{INTRODUCTION}

Palm oil is the largest source of exports for Indonesia with a value of 14.7 billion US Dollars. In 2010, oil palm plantation area was 9 million hectares (Putra et al. 2012), and increased to 12.3 million in subsequent years. Moreover, the production of crude palm oil (CPO) in 2016 reached 35.3 million tons (Directorate General of Estate Crops 2017). In the province of Aceh, palm oil plantation areas were 393,230 ha, with $50.41 \%$ being public estate while $49.59 \%$ were private (BKPM 2017). There are many factors influencing the productivity of palm oil plantation, such as soil fertility, seed quality, climate, technology, labor and the environment (Dilipkumar et al. 2017). Weeds provide benefits and disadvantages in agroecosystems (Petit et al. 2016). Weed invasion is a major problem during the early stage of oil palm plantation (Thongjua and Thongjua 2016) because weeds interfere oil palm growth by competing resources such as moisture, nutrients, and light (Oerke 2006). Although the direct impact of weeds on palm oil is difficult to predict due to its long economic life (20-30 years) (Kuan et al. 1991), the short term impact is closely related to bunch formation, thus indirectly affecting plant productivity. The weeds are composed of grasses, sedges, and broad leave herbs and shrubs which often change according to the crop growth stage which provide specific climatic and environmental condition suitable for specific weed growth (Mohammad et al. 2010). Weeds found in oil palm plantations can be categorized as detrimental weeds and non-detrimental weeds (Prasetyo and Zaman 2016). Competitive weeds strongly compete with the main crops such as Imperata cylindrica, Mikania cordata, Panicum repens, Cyperus rotundus, Chromolaena odorata, Melastoma malabatrichum, Lantana camara (Samedani et al. 2013), Ischaemum muticum and M. micrantha (Quah et al. 1999). Sahid et al. (1992) reported the loss of palm oil production as a result of weeds may vary from $6-20 \%$.

Non detrimental weeds such as Asystasia gangetica, Ageratum conyzoides, Paspalum conjugatum, Nephrolephis biserrata can be tolerated in oil palm plantations, even contribute to prevent soil erosion (Asbur et al. 2016), and some can be made as bioherbicide (Sari et al. 2017), but the populations must be kept in control, (Wibawa et al. 2009). Kustyanti and Horne (1991) conducted an evaluation that the $12 \%$ increase in production of palm oil fresh fruit bunches was affected by a weed, Asystasia gangetica.

Data regarding weed composition on palm oil plantations in Indonesia are limited. However, study conducted on palm oil plantations in Jambi showed the weed composition consisted of 20 families, 47 genera, 56 species and 3934 individuals (Adriadi et al. 2012). The dominant weeds can be identified on ecological and biological aspects through the vegetation analysis method. The species of weeds growing and dominating an area often depends on the soil and local climate, especially the light received (Lubis 1992). The weed species vary from regions, even if the crop is the same (Budiarto 2001), due to the differences in environmental conditions of plants and climatic differences. The purpose of this study furthermore 
was to examine the diversity of weeds in the planting palm oil in different ages.

\section{MATERIALS AND METHODS}

\section{Study site}

The vegetation analysis research conducted at the oil palm plantation of Almuslim University located in the Subdistrict of South Peusangan (planting year in 2012 and 2016) and Peusangan Siblah Krueng, Bireun District, Aceh Province, Indonesia with the planting year 2013 for mature plants and 2014 and 2016 for immature plants.

\section{Research materials and tools}

Some of the equipment used include ovens, roll meters, scissors, stakes, machetes, rulers, calculators, stationery, spray tubes, sewing needles, cameras, glue, and knife. Also, the materials used were spritus, corn yarn, plastic bags, and old newspapers, cardboard, paper, and rope.

\section{Research method}

Analysis of vegetation was based on the squares method and the research conducted through direct observation in the field. The obtained data were analyzed with a descriptive method that described the results based on the conditions found in the field.

The sample observation plots were made by purposive sampling with a size of $1 \mathrm{~m} \mathrm{x} 1 \mathrm{~m}$, totaling 25 slots. Then in each observation plot is made vegetation analysis was carried out by recording the weed population, determining weed dominance, and measuring the biomass. Vegetation analysis was carried out by recording the weed species found in the sample plots in the sample plot, calculating the dominance of each weed species by measuring the biomass. Weed biomass measurement is done by pulling weeds then dividing them based on the type and identified. Each type is counted and recorded as density data. Then put in an envelope made of newspaper and then in the oven and weighed dry weight (to measure dominance). The above data is then used to calculate the density (D), relative density (RD), frequency $(F)$, relative frequency (RF) (Kainde et al. 2011), dominance (D) (Johnston and Gilman 1995), importance value index (IVI) (Brower and Zar 1990), Summed Dominance Ratio (SDR) (MuellerDombois and Ellenberg 1974), and Species Diversity Index (H') Magurran (2004). Before vegetation analysis was conducted, the temperature, humidity and light intensity of the environment in every block of the age of the plants that had been determined using a multimeter was measured.

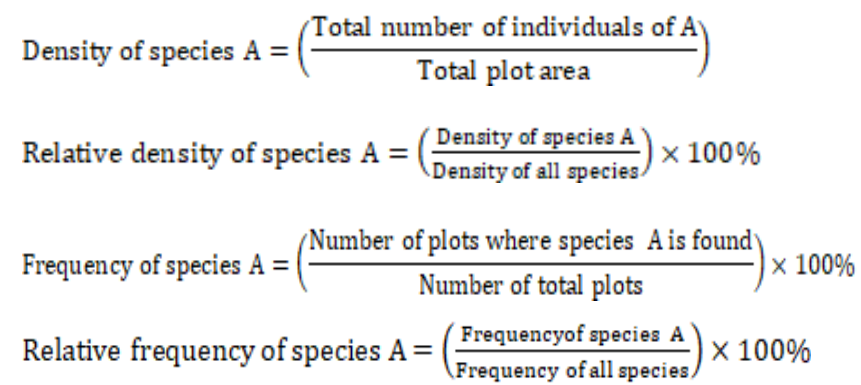

Dominance of species A (D) = Total numbers of individuals of A $\mathrm{x}$ Biomass of species A

Importance Value Index (IVI) = Relative Frequency + Relative Density

Summed Dominance Ratio $($ SDR $)=\underline{\text { IVI }}$

2

$$
H^{\prime}=-\sum_{i=1}^{s} p i \ln p i
$$

Where:

$\mathrm{H}^{\prime}=$ species diversity index

$\mathrm{Pi}=$ importance chance of each species $=n \mathrm{i} / \mathrm{N}$

$\mathrm{ni}=$ number of individuals of each species

$\mathrm{N}=$ the total number of individuals

According Magurran (1988), the classification of diversity value is as follows:

$\mathrm{H}^{\prime}<1$ : Lower diversity

$1<\mathrm{H}^{\prime}<3$ : Moderate diversity

$\mathrm{H}^{\prime}>3$ : High diversity

\section{RESULTS AND DISCUSSION}

\section{Weeds structure}

Different species of weeds were grown in the palm oil plantation Dominant species were then determined by analyzing the vegetation. Table 1 shows the composition of weed species under the stand of oil palm in the planting age of 6, 5, 4 and 2 years (planting year in 2012, 2013, 2014 and 2016). There were 36 species of weeds from 21 families identified which were consists of lawn weed, ferns, broadleaf weeds, and nutgrass with the total number of each individual based on planting year of palm oil being $3540,3148,3731$, and 2910, respectively. Herb weeds of the Acanthaceae family, species of Asystasia intrusa were the most dominant under the stands of palm oil plantations at the age of 6 and 5 years, planting in the year of 2012 and 2013, consecutively. The narrow-leaved weeds from the group of lawn and nutgrass, comprising mainly the Eulesine indica and Cynodon dactylon, dominated the oil palm plants at planting age of 4 and 2 years (planting year 2014 and 2016).

Many vegetation found under the stands of oil palm were generally a mixture of fern, broadleaf, lawn, and nutgrass, but the most dominant mixture was of the group of broadleaf (Table 1). Dominant broadleaf weeds identified were of Acanthaceae family, while of the nutgrass were Poaceae, Graminae, and Cyperaceae. Adriadi et al. (2012) reported that mixture of weed vegetation family was also found in other stands of oil palm plantations in various places, even though the dominant type was not the same. Our research was found the lawn weeds of the species E. indica was the most dominant. Different composition of the dominant weeds under the stand of oil palm previously reported were included Ageratum conyzoides of broadleaf group, Mimosa pudica of nutgrass group (Afrianti et al. 2015); while Axonopus compressus of the lawn group were found in the mature oil 
palm plantation (Prasetyo dan Zaman 2016; Trisna et al. 2018), and Borreria latifolia (type of spud) on the immature oil palm plantation (Susanti 2015).

Asystasia intrusa of the Acanthaceae family is a broadleaf weed commonly found in plantations and land crops and were found as many as 840, 964, 276, and 260 individuals in 2012, 2013, 2014, and 2016 planting years, consecutively. This weed is able to grow well in tropical and subtropical regions and has good tolerance to various types of soil and can be found up to an altitude of 500 meters above sea level (CRC 2003).

The second-largest population of individuals in oil palm plantations is E. indica. Its populations were 548, 120, 860, and 893 in oil palm plantations planted in the year of 2012, 2013, 2016, and 2014, consecutively. This weed is classified as aggressive because of its rapid growth and abundant seeds its produce (Tampubolon et al. 2018). The bone weeds can grow up to 1 meter and propagating themselves through flower which blooms throughout the year and each clump can produce up to 140,000 seeds (Chin 1979; Uva et al. 1997). When compared with weed vegetation on immature and mature oil palm on peatlands found a different type. Syahputra et al. (2011) reported that the types of weeds in immature oil palm on peatlands were dominated by Fimbristylis acuminata, N. biserrata, Elaeis guineensis, Cyperus compressus and Murdannia nudiflora, while in mature oil palm were $F$. acumunata, Digitaria ciliaris, N. biserrata, Davallia denticulata and $C$. compressus. In both location is dominated by the same type of weed, namely $F$. acuminata.

Table 1. Composition of weeds under the stands of oil palm

\begin{tabular}{|c|c|c|c|c|c|}
\hline \multirow{2}{*}{ Family } & \multirow{2}{*}{ Species } & \multicolumn{4}{|c|}{ Number of Individuals } \\
\hline & & Year 2012 & Year 2013 & Year 2014 & Year 2016 \\
\hline Nephrosidaceae & Nephrolepis biserrata & 100 & 104 & 45 & 15 \\
\hline Athyriaceae & Diplazium asperum & 50 & - & 30 & - \\
\hline Polypodiaceae & Cyclosorus aridus & 25 & - & 15 & - \\
\hline Licopodiaceae & Licopodium seanum & 28 & - & - & - \\
\hline Gleicheniace & Dicranapteris linearis & 33 & - & 21 & - \\
\hline \multirow[t]{3}{*}{ Acanthaceae } & Asystasia gangetica & 250 & - & 450 & - \\
\hline & Asystasia intrusa & 840 & 964 & 276 & 260 \\
\hline & Clibadium surinamense & - & 12 & - & - \\
\hline \multirow{4}{*}{ Asteraceae } & Chromolaena odorata & 70 & 3 & 67 & 35 \\
\hline & Mikania micrantha & 57 & 62 & 55 & 20 \\
\hline & Ageratum conyzoides & 13 & 25 & 20 & 55 \\
\hline & Crassocephalum crepidioides & - & 6 & - & - \\
\hline Fabaceae & Colopogonium mисипoides & 41 & 57 & 105 & 35 \\
\hline Melastomataceae & Mellastoma affine & 15 & 14 & 21 & - \\
\hline \multirow{5}{*}{ Poaceae } & Eleusine indica & 548 & 120 & 893 & 860 \\
\hline & Imperata clyndrica & 49 & 31 & 67 & 90 \\
\hline & Panicum repens & 51 & 22 & 64 & 67 \\
\hline & Paspalum conjugatum & 212 & 142 & 320 & 127 \\
\hline & Brachiaria mutica & 137 & 60 & 75 & 39 \\
\hline \multirow[t]{2}{*}{ Leguminoceae } & Mucuna cochinsinensis & 30 & 72 & 15 & - \\
\hline & Pueraria montana & 23 & 34 & 51 & 22 \\
\hline Mimosaceae & Mimosa pudica & 14 & - & 22 & 2 \\
\hline Lytheraceae & Clidemia hirta & 48 & 30 & 50 & - \\
\hline Oxalidaceae & Oxalis barrelieri & 42 & - & 40 & 30 \\
\hline Araceae & Colocasia esculenta & - & 40 & - & - \\
\hline \multirow[t]{3}{*}{ Graminae } & Cyrtococcum oxyphyllum & 233 & 241 & 199 & 30 \\
\hline & Digitaria setigera & 24 & 20 & 29 & 55 \\
\hline & Cynodon dactylon & - & - & - & 755 \\
\hline \multirow[t]{3}{*}{ Rubiaceae } & Borreria laevis. & 53 & 88 & 61 & 75 \\
\hline & Borreria alata & 33 & 78 & 48 & 12 \\
\hline & Borreria latifolia & - & 50 & - & - \\
\hline \multirow{2}{*}{ Verbenaceae } & Stachytarpheta indica & 12 & - & 19 & 2 \\
\hline & Lantana camara & - & 11 & - & - \\
\hline Solanaceae & Solanum torvum & 14 & 25 & 20 & 2 \\
\hline \multirow[t]{2}{*}{ Cyperaceae } & Cyperus kyllingia & 316 & 560 & 422 & 218 \\
\hline & Cyperus rotundus & 121 & 230 & 165 & 101 \\
\hline Euphorbiaceae & Hyptis brevipes & 58 & 47 & 66 & 3 \\
\hline Total & & 3540 & 3148 & 3731 & 2910 \\
\hline
\end{tabular}


Table 2. Ten species dominant of vegetation under the stands of oil palm that has a value of SDR (Summed Dominance Ratio)

\begin{tabular}{|c|c|c|c|c|}
\hline Species & $\mathbf{K R}$ & FR & INP & SDR \\
\hline \multicolumn{5}{|l|}{ Planting year of 2012} \\
\hline Asystasia intrusa & 20.22 & 7.20 & 27.41 & 13.71 \\
\hline Eleusine indica & 11.65 & 6.44 & 18.09 & 9.04 \\
\hline Cyperus kyllingia & 10.86 & 5.30 & 16.17 & 8.08 \\
\hline Nephrolepis biserrata & 6.06 & 3.79 & 9.85 & 4.93 \\
\hline Asystasia gangetica & 5.86 & 5.68 & 11.54 & 5.77 \\
\hline Cyrtococcum oxyphyllum & 4.88 & 6.82 & 11.70 & 5.85 \\
\hline Chromolaena odorata & 4.64 & 6.44 & 11.08 & 5.54 \\
\hline Hyptis brevipes & 4.35 & 4.92 & 9.28 & 4.64 \\
\hline Mikania micrantha & 4.12 & 4.92 & 9.04 & 4.52 \\
\hline Cyperus rotundus & 4.05 & 4.55 & 8.59 & 4.30 \\
\hline \multicolumn{5}{|c|}{ Species Diversity index $\left(\mathrm{H}^{\prime}\right)=5,88$} \\
\hline \multicolumn{5}{|c|}{ Dominance Index $(C)=0,055$} \\
\hline \multicolumn{5}{|l|}{ Planting Year of 2013} \\
\hline Asystasia intrusa & 21.05 & 6.90 & 27.95 & 13.97 \\
\hline Cyperus kyllingia & 17.34 & 6.55 & 23.89 & 11.94 \\
\hline Colocasia esculenta & 7.30 & 2.76 & 10.06 & 5.03 \\
\hline Cyperus rotundus & 6.99 & 5.86 & 12.85 & 6.43 \\
\hline Nephrolepis biserrata & 5.78 & 3.10 & 8.88 & 4.44 \\
\hline Cyrtococcum oxyphyllum & 4.66 & 6.55 & 11.21 & 5.61 \\
\hline Mikania micrantha & 3.98 & 5.17 & 9.15 & 4.57 \\
\hline Hyptis brevipes & 3.25 & 3.45 & 6.70 & 3.35 \\
\hline Solanum torvum & 2.76 & 5.17 & 7.94 & 3.97 \\
\hline Colopogonium mисunoides & 2.49 & 3.45 & 5.94 & 2.97 \\
\hline \multicolumn{5}{|c|}{ Species Diversity index $\left(\mathrm{H}^{\prime}\right)=2,48$} \\
\hline \multicolumn{5}{|l|}{ Dominance Index $(C)=0,061$} \\
\hline \multicolumn{5}{|l|}{ Planting Year of 2014} \\
\hline Eleusine indica & 14.99 & 8.73 & 23.72 & 11.86 \\
\hline Cyperus kyllingia & 13.12 & 7.42 & 20.54 & 10.27 \\
\hline Asystasia gangetica & 9.41 & 7.42 & 16.83 & 8.42 \\
\hline Asystasia intrusa & 6.00 & 6.99 & 12.98 & 6.49 \\
\hline Cyperus rotundus & 5.40 & 6.55 & 11.95 & 5.98 \\
\hline Hyptis brevipes. & 4.72 & 3.49 & 8.21 & 4.11 \\
\hline Colopogonium mucunoides & 4.62 & 3.93 & 8.55 & 4.28 \\
\hline Paspalum conjugatum & 4.40 & 6.55 & 10.95 & 5.48 \\
\hline Cyrtococcum oxyphyllum & 3.94 & 5.24 & 9.18 & 4.59 \\
\hline Chromolaena odorata & 3.87 & 5.24 & 9.11 & 4.56 \\
\hline \multicolumn{5}{|c|}{ Species Diversity index $\left(\mathrm{H}^{\prime}\right)=6,85$} \\
\hline \multicolumn{5}{|c|}{ Dominance Index $(C)=0,053$} \\
\hline \multicolumn{5}{|l|}{ Planting Year of 2016} \\
\hline Cynodon dactylon & 24.49 & 13.16 & 37.64 & 18.82 \\
\hline Eleusine indica & 20.07 & 13.16 & 33.23 & 16.61 \\
\hline Cyperus kyllingia & 10.35 & 7.24 & 17.58 & 8.79 \\
\hline Cyperus rotundus & 7.95 & 7.24 & 15.19 & 7.59 \\
\hline Asystasia intrusa & 7.82 & 6.58 & 14.39 & 7.20 \\
\hline Ageratum conyzoides & 5.24 & 2.63 & 7.87 & 3.94 \\
\hline Chromolaena odorata & 2.93 & 1.97 & 4.91 & 2.45 \\
\hline Paspalum conjugatum & 2.46 & 6.58 & 9.04 & 4.52 \\
\hline Imperata clyndrica & 2.21 & 5.92 & 8.13 & 4.06 \\
\hline Borreria laevis & 2.20 & 4.61 & 6.80 & 3.40 \\
\hline \multicolumn{5}{|c|}{ Species Diversity index $\left(\mathrm{H}^{\prime}\right)=2,20$} \\
\hline Dominance Index $(\mathrm{C})=0,09$ & & & & \\
\hline
\end{tabular}

\section{Weeds dominancy and diversity}

Broadleaves weed species which are dominant on the planting year of 2012 with total relative abundance of $39.19 \%$ are A. intrusa, Asystasia gangetica, Hyptis brevipes, $M$. micrantha and $C$. odorata, while narrow leaves species of grass are more dominant with relative density $31.44 \%$ and the most dominant species is E. indica, Cyperus kyllingia, Cyrtococcum oxyphyllum, and $C$. rotundus. Of weeds from the fern group, there is $N$. biserrata with relative dominance of $6.06 \%$ (Table 2). In the planting year of 2013, there are 6 species of broadleaves weeds dominating, with total relative dominance of $46.68 \%$ which are A. intrusa, Colocasia esculenta, M. micrantha, Hyptis brevipes, Solanum torvum and Colopogonium mucunoides. Of weeds from the fern group, there is $N$. biserrata with relative dominance of $5.78 \%$. Otherwise, species of grass are dominant with relative density $28.99 \%$ are $C$. kyllingia, $C$. rotundus, and C. oxyphyllum, respectively. Dominant weeds of planting group of 2014 are narrow leaves whereas $41.85 \%$ of the weeds composition comprised of five species, and from the aspects of relative density and dominance, represented by E. indica and C. kyllingia. In the planting year of 2016, out of 10 dominant weeds, 6 species are from grass groups, with the most dominant are E. indica and $C$. dactylon. Total relative dominance is $67.53 \%$.

Table 2 presents the relative density, frequency and dominance, the important index value, SDR of 10 dominant weed species, and the dominance and the diversity indexes in each block of the research area. The species diversity index amounted to 5.58 in 2012; 2.48 in 2013; 6.85 in 2014 and 2.20 in 2016, respectively. These values indicated species diversity of weeds under the stands of mature oil palm, which was very high especially in the planting year of 2012 and 2014. According to Magurran (2004), the diversity index value of Shanon can be explained as $\mathrm{H}>3.0$ indicating a very high diversity, $\mathrm{H}=1.5-3.0$ indicating high diversity, $\mathrm{H}=1.0-1.5$ indicating moderate diversity, and $\mathrm{H}<1$ indicating low diversity. Low diversity index indicates that the species found are not so many and only found the same species in each stand. According to Latifah (2004), low species diversity is caused by an area dominated by only certain types. High diversity of species shows that a community has a high complexity, because in that community there is an interaction between high species. Thus, it is clear that palm oil plantation of the planting year of 2012-2016 dominated by broadleaves weed and narrow leaves weed (grass), with the most dominant species is $A$. intrusa of the broadleaves weed and $E$. indica of the grass group.

A community has a high species diversity if composed of many varieties. Otherwise, it is considered to have a low species diversity. From the observation, there was a considerable difference between the range of values in some observation stations. However, most of the weed species found in this research were the common ones found in plantations, either of palm oil, rubber or natural forests (Rembold et al. 2017). In addition, the high diversity of the research plots was caused by the spacing of the width of the palm tree. The wider growth space under oil palm stands provides an opportunity for weeds to develop by utilizing available nutrients, water, sunlight, and space.

From Table 2, the weeds from the Acanthaceae family of the species A. intrusa was the most dominant species 
under the stands of oil palm especially in the planting year of 2012 and 2013 with the highest values of relative density, frequency and dominance, importance value index, and the highest SDR. These weeds were classified as types of herbaceous plant/mainland herb, a soft trunked and vascular plant. A. intrusa was found in at least 19 sample slots of the 20 slots observed. Apart from A. intrusa, there was also at least one type of weed with high value of relative density, frequency, and dominance, importance value index, and SDR. For example, in the block planting in the year 2012, 2013, 2014 and 2016, species with the highest value of relative density, frequency, and dominance, importance value index, and SDR were $E$. indica, C. kyllingia, A. intrusa, and C. dactylon. While the weeds with the lowest value of SDR in the group of planting years of 2012, 2013, 2014 and 2016 consecutively were $C$. rotundus, $C$. mucunoides, $C$. odorata, and $B$. laevis. This result of SDR lower compared with result Adriadi et al. (2012), which showed that $P$. conjugatum was highest SDR $19.48 \%$ (1029 individuals), and the lowest was Cuphea platycentra SDR 0,19\% (2 individuals) in palm oil plantation. The highest important value in 2012 and 2013 were of the species of A. intrusa (27.41 and 27.95 , respectively) while in 2014 and 2016, the weed with the highest importance value index was E. indica (23.72) and C. dactylon (37.64) (Figure 1).
The mainland weeds growing in the plantation is dependent on the type of estate plants, soil type, climate, and plantation patterns (Samedani et al. 2015). Generally, the degree of competition between weeds and plants depends on the density of weeds type, plant varieties, and fertilization rate. This means the weeds differ from one region to another, although the crop is the same (Nufvitarini et al. 2016). Hasanuddin et al. (2012), stated that various species have distinct abilities to compete differently for morphological and physiological characteristics, while the density of weed reduces the yield.

The year of palm oil planting determines the condition of the land. For instance, field is shaded if the palm oil tree is older. From the aspects of danger level, weeds that thrive in the oil palm plantation of all planting year (2012-2016) belong to dangerous weed and non-dangerous weed categories.

Based on the vegetation analysis, A. intrusa was grown more under the stands of palm oil in 2012 and 2013. These plants could potentially be used as land covers because of the convenience of the auspices. Very few weed species grow in shaded land, including the lawn which provides the added value for A. intrusa toused as a land cover plants, especially under the stands of palm oil and make it a beneficial.
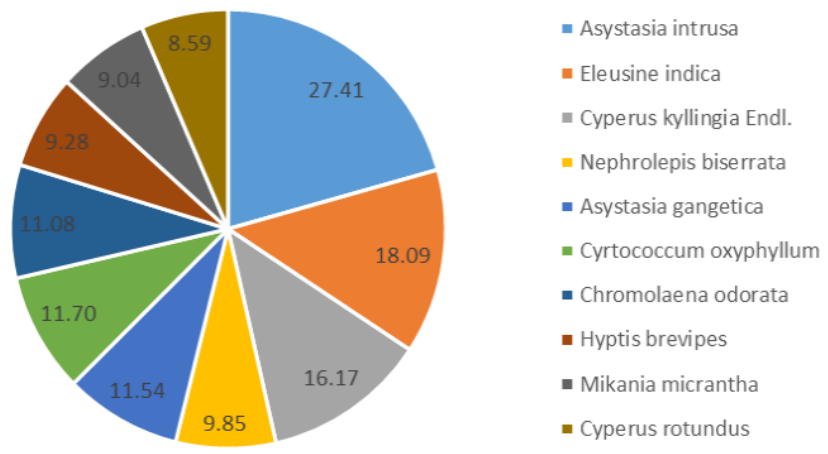

A
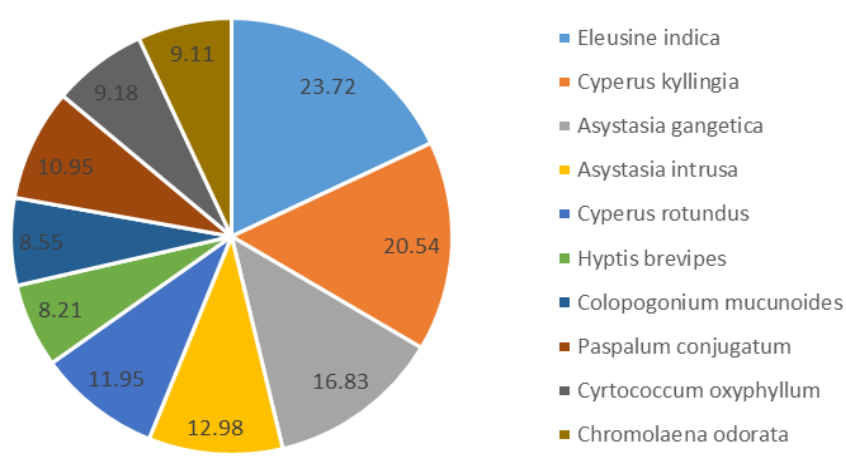

$\mathbf{C}$

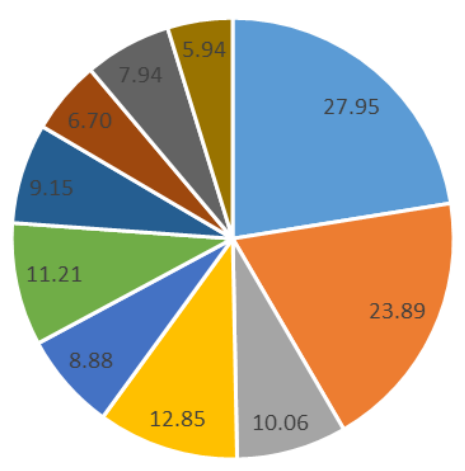

- Asystasia intrusa

- Cyperus kyllingia

- Colocasia schott

= Cyperus rotundus

- Nephrolepis biserrata

- Cyrtococcum oxyphyllum

- Mikania micrantha

- Hyptis brevipes Poit.

- Solanum torvum

- Colopogonium mucunoides
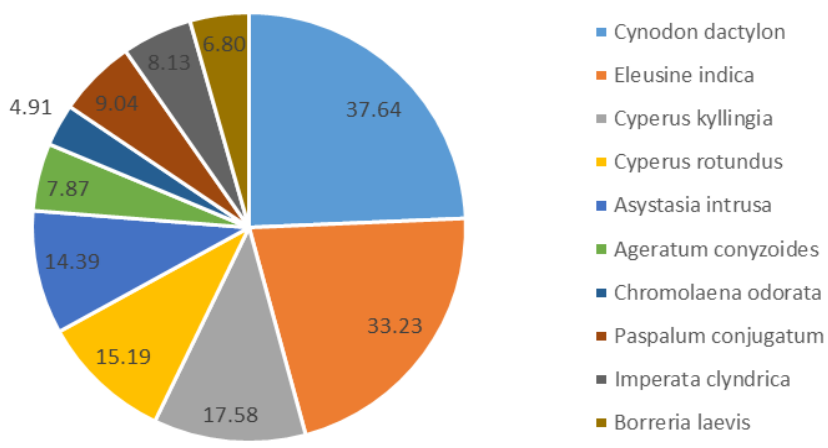

D

Figure 1. The important value index of weeds in year planting of oil palm: A. 2012, B. 2013, C. 2014, D. 2016 
Table 3. Environmental conditions under the stands of oil palm

\begin{tabular}{lcccc}
\hline \multirow{2}{*}{ Environmental factors } & \multicolumn{4}{c}{ Planting year } \\
\cline { 2 - 5 } & $\mathbf{2 0 1 2}$ & $\mathbf{2 0 1 3}$ & $\mathbf{2 0 1 4}$ & $\mathbf{2 0 1 6}$ \\
\hline Air temperature $\left({ }^{\circ} \mathrm{C}\right)$ & 29.51 & 30.39 & 30.4 & 30.1 \\
Air humidity $(\%)$ & 72.5 & 70.7 & 68.9 & 67.3 \\
Light intensity (lux) & 1456 & 1587 & 2703 & 2908 \\
Soil pH & 5.13 & 5.21 & 5.7 & 5.86 \\
Soil moisture $(\%)$ & 5.6 & 5.2 & 4.7 & 4.7 \\
Soil temperature $\left({ }^{\circ} \mathrm{C}\right)$ & 26.1 & 26.32 & 27 & 27.4 \\
\hline
\end{tabular}

Environmental conditions under the stands of palm oil are presented in Table 3. The year 2012 and 2013 has the lowest levels of light intensity and temperature compared to the year 2016. The analysis result of vegetation showed that $A$. intrusa grow well under the stands of mature palm oil particularly in the planting year of 2012 and 2013 compared to the planting year of 2014 and 2016. The sunlight factor is one of the important variables for the growth of $A$. intrusa, where it can grow well in the more shaded conditions with lower light intensity.

\section{Abiotic environmental factors}

Measurements of abiotic environmental factors in the research area are presented in Table 3 . The diversity of the vegetation type growing in palm oil plantations was influenced by the growth environment. According to Sastroutomo (1990), the type of vegetation growing from one place to another is different. This is due to the fact that vegetation adapts to environmental conditions. The research area had high temperature and light intensity since it is situated lowland (Table 3). It was suitable as the breeding grounds of the rapid $A$. intrusa. With such environmental factors, this species was more dominant than others. This was in accordance with its characteristics. It has a high tolerance to unfavorable environmental conditions and has a specific strategy for exploiting the habitat. For instance, in the shaded area, it produces more vegetative organs, and more generative organs in open areas.

Table 3 shows the abiotic environment in palm oil plantations are shaded with humidity above $65 \%$ and low enough sunlight intensity. This showed that $A$. intrusa is shade-tolerant vegetation since it has a higher SDR value than other vegetation. On the basis of immature palm oil (planting year in 2014 and 2016) with the high light intensity, the dominant weed was lawn/nutgrass. The difference between the age of oil palm plantations due to the growing competition in the new land was very small and therefore the weeds grew very easily. The high level of frequency and relative frequency of weeds or competition depends on rainfall, varieties, soil conditions, density, the duration plants and weeds compatibility, and age of the plant at the beginning of competition. According to Faisal et al. (2011), physically weeds compete with plants for space, light and chemically for water, nutrients, and gas.

The composition of weeds consists of 36 species and 21 families made of lawn, broadleaf, and nutgrass with the total number of each individual based on the year of palm oil planting being 3540, 3148, 3731, 2910. The relative density value of the highest weeds (A. intrusa) was found in the planting year group of 2012 and 2013 reached $20.22 \%$ and $21.05 \%$, respectively. In 2014, the highest weed relative density on E. indica amounted to $14.99 \%$, and in 2016, the highest weed relative density on $C$. dactylon with $24.49 \%$. The importance value of the highest weeds in four groups in planting year of oil palm was also in line with the relative density. The highest importance value was $A$. intrusa by the year of planting in 2012 and 2013, amounting to 27.41 and 27.95 and in 2014 and 2016, totaling to 23.72 and 37.64 was $E$. indica and $C$. dactylon. The value of the highest species diversity of 6.85 was found in the planting year group in 2014, followed by 2012 of 5.88, indicating a very high diversity.

\section{ACKNOWLEDGEMENTS}

The authors express the appreciation and gratitude to the directorate of research and community service (DRPM) of The Ministry of Research, Technology and Higher Education under contract number: 235/SP2H/LT/DRPM/ 2019 for research funding on the basic research scheme.

\section{REFERENCES}

Adriadi A, Chairul, Solfiyani. 2012. Analysis of weed vegetation on oil palm plantations (Elaeis guineensis Jacq) at Kilangan Muaro Bulan Batang Hari. J Biol 1 (2): 108-115.

Afrianti I, Yolanda R, Purnama AN. 2015. Analysis of weed vegetation in oil palm plantations (Elaeis guineensis Jacq.) at Suka Maju Village Sub-District of Rambah, District of Rokan Hulu. Jurnal Mahasiswa FKIP Universitas Pasir Pengaraian 1 (1):-

Asbur Y, Yahya S, Murtilaksono K, Sudradjat, Sutarta ES. 2016. The roles of Asystasia gangetica (L.) T. Anderson and ridge terrace in reducing soil erosion and nutrient losses in oil palm plantation in South Lampung, Indonesia. J Trop Crop Sci 3 (2): 49-55.

BKPM (Badan Koordinasi Penanaman Modal). 2017. Regional superior commodities.

http://regionalinvestment.bkpm.go.id/newsipid/id/commodityarea.php ?ia $=11 \& \mathrm{ic}=2$.

Brower JE, Zar JH. 1990. Field and Laboratory Methods for General Ecology. Wm.C. Brown company Publisher, Dubuque, IA.

Budiarto. 2001. The Controlling of Palm Oil Weed in Kebun Sekunyir PT Indotruba Tengah, Kalimantan Tengah. [B.Sc Thesis]. Institut Pertanian Bogor, Bogor. [Indonesian]

Chin HF. 1979. Weed seed-a potential source of danger. Proceedings of the Plant Protection Seminar. 22-23 September 1979.

CRC. 2003. Weed management guide: Asystasia gangetica ssp. micrantha In: Alert List for Environmental Weeds. Department of the Environment and Heritage and the CRC for Australian Weed Management, CSIRO, Canberra.

Dilipkumar M, Chuah TS, Goh SS, Sahid I. 2017. Weed management issues, challenges, and opportunities in Malaysia. Crop Prot. DOI: 10.1016/j.cropro.2017.08.027.

Directorate General of Estate Crops. 2017. Indonesian plantation statistics 2015-2017: the oil palm. Direktorat Jenderal Perkebunan, Kementerian Pertanian, Jakarta. [Indonesian]

Faisal R, Siregar EBM, Anna N. 2011. Inventory of weeds in young plant of Eucalyptus spp. Peronema For Sci J 2 (2): 44-49.

Hasanuddin, Erida G, Safmaneli. 2012. Effect of weed competition Synedrella nodiflora $\mathrm{L}$. at various densities on soybean growth and yield. J Agrista 16 (3): 146-152.

Thongjua J, Thongjua T. 2016. Effect of Herbicides on Weed Control and Plant Growth in Immature Oil Palm in the Wet Season Nakhon Si Thammarat, Thailand. Intl J Agric Technol 12 (7.1):1385-1396. 
Johnston, Gillman M. 1995. Tree population studies in low diversity forest, Guyana. I. Floristic composition and stand structure. Biodiver Conserv 4: 339-362.

Kainde RP, Ratag SP, Tasirin JS, Faryanti D. 2011. Analysis of vegetation in Gunung Tumpa forest. Eugenia 17 (3): 1-11.

Kuan CY, Ann LS, Ismail AA, Leng T, Fee CG, Hashim K. 1991. Crop loss by weeds in Malaysia. In: Lee SA, Kon KF (eds.). Proceeding of the Third Tropical Weed Science Conference. MAPPS, Kuala Lumpur.

Kustyanti T, Horne P. 1991. The Effect of Asystasia on the growth of young rubber in polybags. CR-CRSP Project. Deli Serdang. USAID, Washington, DC.

Latifah S. 2004. Pertumbuhan dan Hasil Tegakan Eucalyptus grandis di Hutan Tanaman Industri. ITI Jurusan Kehutanan Fakultas Pertanian Universitas Sumatera Utara, Medan. [Indonesian]

Lubis AU. 1992. Oil palm (Elaeis guineensis Jacq.) in Indonesia. Pusat Penelitian Perkebunan Marihat-Bandar Kuala, Pematang Siantar. PPKS, Medan. [Indonesian]

Magurran AE. 1988. Why Biodiversity? In: Ecological Diversity and Its Measurement. Springer, Dordrecht.

Magurran AE. 2004. Measuring Biological Diversity. Blackwell Publishing, New York.

Mohammad R, Wibana W, Mohayidin MG, Puteh AB, Juraimi AS Awang Y, Mohd Lassim MB. 2010. Management of mixed weeds in young oil-palm plantation with selected broad-spectrum herbicides. Pertanika J Agric Sci 33 (2): 193-203.

Mueller-Dombois D, Ellenberg HH.1974. Aims and Methods of Vegetation Ecology. John Wiley and Sons, New York.

Nufvitarini W, Zaman S, Junaedi A. 2016. Oil palm weeds management: case study in south Kalimantan. Bul Agrohorti 4 (1): 29-36.

Oerke EC. 2006. Crop losses to pests. J Agric Sci 144 (1): 31-43

Petit S, Gaba S, Grison AL, Meiss H, Simmoneau B, Munier-Jolain N, Bretagnolle V. 2016. Landscape-scale management affects weed richness but not weed abundance in winter wheat fields. Agric Ecosyst Environ 223: 41-47.

Prasetyo H, Zaman S. 2016. Weed control of oil palm plantations (Elaeis guineensis Jacq.) on Padang Halaban, Sumatera Utara. Bul Agrohorti 4 (1): 87-93.

Putra ETS, Simatupang AF, Supriyatna, Waluyo S, Indradewa D. 2012 The growth of one-year-old oil palms intercropped with soybean and groundnut. J Agric Sci 4 (5): 169-180.
Quah YT, Chew PS, Kiew R. 1999. An integrated weed management system for Asystasia gangetica subsp. micrantha in oil palm estates. In: Preprints. 1999. PORIM Int Palm Oil Conf. Palm Oil Research Institute, Malaysia, Kuala Lumpur.

Rembold K, Mangopo H, Tjitrosoedirdjo SS, Kreft H. 2017. Plant diversity, forest dependency, and alien plant invasions in tropical agricultural landscapes. Biol Conser 213 (2017): 234-242. DOI: 10.1016/j.biocon.2017.07.020.

Sahid I, Hamzah A, Aria PM. 1992. Effect of paraquat and alachlor on soil microorganism in peat soil. Pertanika 15: 121-125.

Samedani B, Juraimi AS, Anwar MP, Rafii MY, Sheikh Awadz SH, Anwar MP, Anuar AR. 2015. Effect of cover crops on weed suppression in oil palm plantation. Intl J Agric Biol 17 (2):251-260.

Samedani B, Juraimi AS, Anwar MP, Rafii MY, Sheikh Awadz SH, Anuar AR. 2013. Competitive Interaction of Axonopus compressus and Asystasia gangetica under contrasting sunlight intensity. Sci World J. DOI: 10.1155/2013/308646

Sari VI, Hafif RA, Soesatrijo J. 2017. The using of Chromolaena odorata extract as a pre-grown bioherbicide for weed control in oil palm plantations. J Citra Widya Edukasi 9 (1): 71-79.

Sastroutomo.1990. Ekologi Gulma. Gramedia Pustaka Utama, Jakarta. [Indonesian]

Susanti Y, Febrinova R. 2015. Inventory of weeds on oil palm plantations (Elaeis guineensis Jacq.) in Tambusai Utara Sub-District of Rokan Hulu District. J Sungkai 3 (2): 18-23.

Syahputra E, Sarbino, Siti D. 2011. Weeds assessment di perkebunan kelapa sawit lahan gambut. J Perkebunan Lahan Trop 1 (1): 37-42.

Tampubolon K, Purba E, Hanafiah DS, Basyuni M. 2018. Population Distribution and Resistance Classification of Eleusine indica to Glyphosate on Oil Palm Plantations in Deli Serdang Regency. Caraka Tani: J Sustain Agric 33 (2): 146-152. DOI: 10.20961/carakatani.v33i2.24300

Trisna, Wiryono, Apriyanto E. 2018. Lower plants in old oil palm plantations and young oil palm with rejuvenation techniques in PT. Bio Nusantara Teknologi. Naturalis-J Penelitian Pengelolaan Sumberdaya Alam dan Lingkungan 7 (2): 61-69.

Uva RH, Neil JC, Di Tomaso JM. 1997. Weeds of the Northeast. Cornell University Press, Ithaca.

Wibawa W, Mohamad R, Juraimi AS, Omar D, Mohayidin MG, Begum M. 2009. Weed control efficacy and short term weed dynamic impact of three non-selective herbicides in immature oil palm plantation. Int J Agric Biol 11 (2): 145-150. 